\title{
Spatiotemporal Variation of Abattoir Operation on Soil Quality Dynamics in Umuahia South, Abia State, Nigeria
}

\section{${ }^{* 1}$ CHIKWENDU, MU; ${ }^{2}$ UCHENDU, UI; ${ }^{1}$ OCHOR, NO}

\author{
${ }^{l}$ Department of Forestry and Environmental Management, ${ }^{2}$ Department of Environmental Management and Toxicology, Michael Okpara \\ University of Agriculture Umudike, Abia State, Nigeria \\ *Corresponding Author Email:nwogwugwu.michael@gmail.com,udouche@yahoo.com \\ Tel: 08065254590
}

\begin{abstract}
Heaps of abattoir wastes are commonly sighted in most abattoirs in Nigeria which constitute serious environmental and public health hazards. The study aimed at assessing the spatiotemporal variation of abattoir operation on soil quality in Umuahia South, Abia State, Nigeria. A total of nine composite samples were collected from three different locations at graded distance. Conventional analytical methods were employed for the determination of physicochemical parameters. The results indicate that the mean $\mathrm{pH}$ value was 5.90 , organic carbon $1.31 \%$ and $2.27 \%$ organic matter respectively. Mean values of $2.10 \mathrm{~g} / \mathrm{kg}$ and $3.66 \mathrm{mg} / \mathrm{kg}$ were observed for total nitrogen and available phosphorus respectively. The exchangeable cations were observed to be $0.53 \mathrm{Cmol} / \mathrm{kg}, 2.31 \mathrm{Cmol} / \mathrm{kg}, 0.49 \mathrm{Cmol} / \mathrm{kg}$ and $0.67 \mathrm{Cmol} / \mathrm{kg}$ for Potassium, Sodium, Calcium and Magnesium respectively. The mean cation exchange capacity was $8.70 \mathrm{Cmol} / \mathrm{kg}$, mean percentage base saturation was $46.04 \%$ and mean of electrical conductivity was 5.96 , Mean values of $5.06,1.70 \%$, $2.94 \%, 2.81 \mathrm{~g} / \mathrm{kg}, 5.28 \mathrm{mg} / \mathrm{kg}, 0.63 \mathrm{Cmol} / \mathrm{kg}, 3.17 \mathrm{Cmol} / \mathrm{kg}, 0.50 \mathrm{Cmol} / \mathrm{kg}, 0.51 \mathrm{Cmol} / \mathrm{kg}, 8.64 \mathrm{Cmol} / \mathrm{kg}$ and $55.29 \%$, percentage organic carbon and organic matter, total nitrogen, available phosphorus, exchangeable potassium, sodium, calcium and magnesium, cation exchange capacity and percentage base saturation, electrical conductivity respectively. This study reveals that the possible source of contaminants is due to the unhygienic manner of handling meat in abattoirs and concludes that the results obtained indicated that the quality of the soil is negatively affected by the activities of the abattoir. Regular inspection of abattoirs and strict enforcement of law is hereby recommended.
\end{abstract}

DOI: $\underline{\text { https://dx.doi.org/10.4314/jasem.v23i7.2 }}$

Copyright: Copyright (C) 2019 Chikwendu et al. This is an open access article distributed under the Creative Commons Attribution License (CCL), which permits unrestricted use, distribution, and reproduction in any medium, provided the original work is properly cited.

Dates: Received: 06 June 2019; Revised: 10 July 2019; Accepted 20 July 2019

Keyword: Abattoir, Effluent, Pollution, Public health hazard

The continuous drive to increase meat production for the protein needs of the ever-increasing world population has some pollution problems attached. Pollution arises from activities in meat production as a result of failure in adhering to Good Manufacturing Practices (GMP) and Good Hygiene Practices (GHP) (Akinro et al., 2009). Consideration is hardly given to safety practices during animal transport to the abattoir, during slaughter and during dressing (Singh and Neelam, 2011). Abattoir waste can be defined as waste or waste water from an abattoir which could consist of the pollutants: internal organs, carcasses, animal faeces, blood, fat, hides, carcass trimmings, paunch content and urine. Abattoir waste just like any other waste can be detrimental to humans and the environment if definite precautions are not taken. In the Nigerian livestock industry, slaughter houses are littered with non-meat products and wastes that need to be recycled into useful by-products for further agricultural and other industrial uses (Osibanjo and Adie, 2007). This constitutes public health risks and nuisance in most slaughter houses spread across
Nigerian markets, producing air, soil, and water pollution as well as infestation of flies and other disease vectors. For hygienic reasons abattoirs use large amount of water in processing operations; this produces large amount of waste water. The major environmental problem associated with this abattoir waste water is the large number of suspended solids and liquid waste as well as odour generation (Gauri, 2006). This situation has been reported by Nwachukwu, (2006) which observed that the establishment and management of abattoirs and wastes in Nigeria have always been regarded as social services by all the three tiers of government. Each of these government authorities has for many years neglected its function and has been apathetic about taking over responsibilities (Nwachukwu, 2006).

Effluent from slaughterhouses has also been known to contaminate both surface and groundwater because during abattoir processing, blood, fat, manure, urine and meat tissue are lost to the wastewater streams (Bello and Oyedemi, 2009). In Nigeria, many abattoirs

*CorrespondingAuthorEmail:nwogwugwu.michael@gmail.com,udouche@yahoo.com Tel: 08065254590 
dispose their effluents directly into streams and rivers without any form of treatment and the slaughtered meat is washed by the same water. Leaching into groundwater is a major part of the concern, especially due to the recalcitrant nature of some contaminants (Muhirwa et al.,2010).

The processes of adsorption and trapping by fine sandy materials, clays and organic matter can remove pathogenic organisms and some dissolved organic matter during passage of polluted water through the soil, thus reducing the microbial load. However, if there is too high departure of conditions from normalcy, beyond the carrying capacity of the natural process, diversity of autochthonous species could diminish while count of individual species that are able to survive may increase with possibility of grave consequences on groundwater (Osemwota, 2010). Adeyemo et al., (2009) observed that facilities for waste recovery, treatment, and reuse are either inadequate or non-existent in most Nigerian abattoirs. Thus, wastes are indiscriminately and improperly discharged and constitute environmental hazards. Leachates from their serial decomposition processes have the potential to pollute nearby surface water, with enteric pathogens and excess nutrients which may percolate into the underlying aquifers and contaminate hand-dug wells. Blood constitutes the highest pollution load of all the components of abattoir effluents, followed by fat. Blood, one of the major dissolved pollutants in abattoir waste water, has the highest COD of any effluent from abattoir operations (Aniebo et al., 2009).

The major characteristics of abattoir wastes are high organic strength, sufficient organic biological nutrients, adequate alkalinity, relatively high temperature $\left(20\right.$ to $\left.30^{\circ} \mathrm{C}\right)$ and free of toxic material. Abattoir wastewaters with the above characteristics are well suited to anaerobic treatment and the efficiency in reducing the BOD ranged between 60 and $90 \%$ (Chukwu, 2008). The high concentration of nitrates in the abattoir wastewater also shows that the wastewater could be treated by biological processes. Due to the economic situation of Nigeria, little interest has been shown to the effects of wastes from abattoirs to the environment (Singh and Neelam, 2011). It is also important to note that for one to understand the methods of handling and disposing waste there is need for a vivid knowledge of the basic characteristics of the waste in question and its quantity (Chukwu et al., 2011).

This study aimed at assessing the spatiotemporal variation of abattoir operation on soil quality and address the possible ways of managing abattoir activities in Umuahia South, Abia Sate, Nigeria.

\section{MATERIALS AND METHOD}

Study Area: Umuahia South is located within the lowland rainforest zone in Nigeria (Keay, 1989). On an altitude of $148 \mathrm{~m}$ above sea level. It lies on latitude $05^{\circ} 25^{\prime} \mathrm{N}$ and longitude $07^{0} 30^{\prime} \mathrm{E}$. Umuahia South has loamy sandy to sandy loam soil and a mean top soil $\mathrm{pH}$ of 4.7. It has the following mean climatic data: rainfall of $2230 \mathrm{~mm}$ with a double peak rainfall pattern in July and a September, mean maximum and minimum temperature of $32^{\circ} \mathrm{C}$ and $23^{\circ} \mathrm{C}$ respectively, relative humidity range of $66-80 \%$ (NRCRI, 2002), Umuahia South has an area of $140 \mathrm{~km}^{2}$ and a population of 138,570 (National Population Census, 2006).

Soil sampling method: Soil sampling was carried out according to the methods of Zaku (2006). A total of nine composite samples were collected from three different locations. Three composite and replicates samples each were collected from the sampling locations at a depth of 0 to $15 \mathrm{~cm}$, and at a distance interval of $10 \mathrm{~m}, 20 \mathrm{~m}$ and $30 \mathrm{~m}$ with a control $100 \mathrm{~m}$ meter away.

Soil Sample Analysis: Preliminary routine laboratory practices of air drying, crushing and sieving were done. Soil $\mathrm{pH}$ was determined using 1:1 soil to distilled water, and measured with a glass electrode $\mathrm{pH}$ meter (Bates, 1954). Percentage Organic Carbon (OC) and Organic Matter (OM) were determined using WalkleyBlack method (Walkley and Black, 1934). Total nitrogen $(\mathrm{N})$ was determined using micro Kjedhal digestion distillation method (Bremner and Mulvaney, 1982). Available phosphorus (P) was determined using Bray-1 method (Bray and Kurtz, 1945). Exchangeable cation was determined using ammonium acetate $\left(\mathrm{NH}_{4} \mathrm{OA}_{\mathrm{C}}\right)$ extraction solution method; sodium $(\mathrm{Na})$ and potassium $(\mathrm{K})$ were measured using Flame Photometer, calcium $(\mathrm{Ca})$ and magnesium $(\mathrm{Mg})$ were measured using EDTA titration. Cation exchange capacity (CEC) was determined using $1 \mathrm{~N}$ neutral ammonium acetate $\left(\mathrm{NH}_{4} \mathrm{OA}_{\mathrm{C}}\right)$ solution. Percentage base saturation (PBS) was determined.

Statistical Analysis: Significance difference between means of various abattoir waste sites was tested at $\mathrm{P} \leq$ 0.05 level of significance, using the Least Significant Difference (LSD).

\section{RESULTS AND DISCUSSION}

Table 1, The Physicochemical properties of the old effluent discharging area samples reveals that mean $\mathrm{pH}$ value of 5.90 organic carbon $1.31 \%$ and $2.27 \%$ 
organic matter respectively. Mean values of 2.10 $\mathrm{mg} / \mathrm{kg}$ and $3.66 \mathrm{mg} / \mathrm{kg}$ were observed for total nitrogen and available phosphorus respectively. The exchangeable cations were observed to be $0.53 \mathrm{Cmol} / \mathrm{kg}, \quad 2.31 \mathrm{Cmol} / \mathrm{kg}, \quad 0.49 \mathrm{Cmol} / \mathrm{kg}$ and $0.67 \mathrm{Cmol} / \mathrm{kg}$ for Potassium, Sodium, Calcium and Magnesium respectively. The mean cation exchange capacity was $8.70 \mathrm{Cmol} / \mathrm{kg}$, mean percentage base saturation was $46.04 \%$ and mean of electrical conductivity was 5.96. Table 2 reveals the chemical properties of the new effluent discharging area samples. The results indicated the mean values of $5.06, \quad 1.70 \%, \quad 2.94 \%, \quad 2.81 \mathrm{mg} / \mathrm{kg}, \quad 5.28 \mathrm{mg} / \mathrm{kg}$, $0.63 \mathrm{Cmol} / \mathrm{kg}, \quad 3.17 \mathrm{Cmol} / \mathrm{kg}, \quad 0.50 \mathrm{Cmol} / \mathrm{kg}$, $0.51 \mathrm{Cmol} / \mathrm{kg}, 8.64 \mathrm{Cmol} / \mathrm{kg}$ and $55.29 \%, 5.96$ for $\mathrm{pH}$, percentage organic carbon and organic matter, total nitrogen, available phosphorus, exchangeable potassium, sodium, calcium and magnesium, cation exchange capacity and percentage base saturation, electrical conductivity respectively.

Table 1: Physicochemical properties of old abattoir effluent discharging area samples

\begin{tabular}{llllll}
\hline Treatment & 10 meters & 20 meters & 30 meters & Control & Mean/S.E \\
\hline Sand & 75.97 & 77.63 & 79.63 & 93.3 & $77.74 \pm 1.06$ \\
Silt & 20.7 & 23.7 & 28.57 & 1.45 & $24.32 \pm 2.27$ \\
Clay & 6.55 & 6.67 & 5.89 & 5.98 & $6.37 \pm 0.26$ \\
PH & 5.91 & 6.1 & 5.74 & 6.09 & $5.90 \pm 0.103$ \\
\%OC & 1.21 & 1.08 & 1.65 & 0.78 & $1.31 \pm 0.17$ \\
OM & 2.09 & 1.87 & 2.85 & 1.34 & $2.27 \pm 0.29$ \\
N & 2.08 & 2.24 & 1.99 & 0.89 & $2.10 \pm 0.73$ \\
P & 3.49 & 3.92 & 3.56 & 2.99 & $3.66 \pm 0.13$ \\
K & 0.54 & 0.55 & 0.5 & 0.58 & $1.59 \pm 0.015$ \\
Na & 2.22 & 2.47 & 2.24 & 3.09 & $2.31 \pm 0.08$ \\
Ca & 0.5 & 0.48 & 0.5 & 0.64 & $0.49 \pm 0.0067$ \\
Mg & 0.74 & 0.51 & 0.77 & 0.51 & $0.67 \pm 0.082$ \\
CEC & 8.62 & 8.8 & 8.69 & 7.23 & $8.70 \pm 0.052$ \\
PBS & 46.4 & 45.57 & 46.14 & 68.43 & $46.04 \pm 0.25$ \\
EC & 4.8 & 5.61 & 5.87 & 3.26 & $5.43 \pm 0.32$ \\
\hline
\end{tabular}

Table 2: Physicochemical properties of new abattoir effluent discharging area samples

\begin{tabular}{llllll}
\hline Treatment & 10 meters & 20 meters & 30 meters & Control & Mean/S.E \\
\hline Sand & 72.45 & 80.33 & 90 & 88.6 & $80.93 \pm 5.08$ \\
Silt & 15.67 & 18.04 & 21.5 & 2.04 & $18.40 \pm 1.69$ \\
Clay & 5.88 & 5.9 & 5.77 & 6.03 & $5.85 \pm 0.040$ \\
PH & 5.22 & 5.46 & 4.49 & 6.09 & $5.06 \pm 0.29$ \\
\%OC & 1.85 & 1.35 & 1.92 & 0.78 & $1.70 \pm 0.18$ \\
OM & 3.18 & 2.22 & 3.32 & 1.34 & $2.95 \pm 0.35$ \\
N & 2.04 & 3.44 & 2.94 & 0.89 & $2.81 \pm 0.41$ \\
P & 5.64 & 5.22 & 4.98 & 2.99 & $5.28 \pm 0.19$ \\
K & 0.72 & 0.51 & 0.58 & 0.58 & $0.63 \pm 0.062$ \\
Na & 2.8 & 3.55 & 3.16 & 3.09 & $3.17 \pm 0.211$ \\
Ca & 0.46 & 0.53 & 0.51 & 0.64 & $0.50 \pm 0.021$ \\
Mg & 0.56 & 0.45 & 0.51 & 0.51 & $0.51 \pm 0.032$ \\
CEC & 8.51 & 8.86 & 8.55 & 7.23 & $8.64 \pm 0.11$ \\
PBS & 52.64 & 57.67 & 55.56 & 68.43 & $55.29 \pm 1.46$ \\
EC & 6.61 & 5.87 & 5.41 & 3.26 & $5.96 \pm 0.35$ \\
\hline
\end{tabular}

Table 3: Mean Physicochemical properties of the control, old and new effluent discharging area samples

\begin{tabular}{|c|c|c|c|c|c|c|c|c|c|c|c|c|c|c|c|}
\hline Location & Sand & Silt & Clay & PH & OC\% & OM & $\mathbf{N}$ & $\mathbf{P}$ & $\mathbf{K}$ & $\mathrm{Na}$ & $\mathrm{Ca}$ & $\mathrm{Mg}$ & CEC & PBS & EC \\
\hline Old & 77.74 & 24.32 & 6.37 & 5.9 & 1.31 & 2.27 & 2.1 & 3.66 & 0.53 & 2.31 & 0.49 & 0.67 & 8.7 & 46.04 & 5.96 \\
\hline New & 80.93 & 18.4 & 5.85 & 5.06 & 1.7 & 2.94 & 2.81 & 5.28 & 0.63 & 3.17 & 0. & 0.51 & 8.64 & 55.29 & 5.96 \\
\hline Control & 90.95 & 1.75 & 6.01 & 6.09 & 0.78 & 1.34 & 0.87 & 2.99 & 0.58 & 3.09 & 0.64 & 0.51 & 7.23 & 68.43 & 3.26 \\
\hline LSD & 2.84 & NS & NS & $0.65^{\prime}$ & $0.52 *$ & 0.89 * & 0.82 * & 0.81 & NS & 0.57 * & 0.06 * & NS & 0.27 * & $3.03 *$ & 0.23 * \\
\hline
\end{tabular}

Table 3 reveals the mean chemical properties of the control, old and new effluent discharging area samples. The low $\mathrm{pH}$ values on both old and new effluent discharging areas indicated that abattoir effluent had the ability to lower the $\mathrm{pH}$ value of soils. The control samples had the mean value of 6.09 , which is not statistically different $(\mathrm{P}<0.05)$ from 5.90 observed from old effluent discharging area samples, but statistically different $(\mathrm{P}<0.05)$ with 5.06 for the new effluent discharging area samples. High percentage organic carbon and organic matter were observed from the samples taken from effluent discharging areas. The results indicated significant difference between the effluent discharging areas and the control area. Both old and new effluent discharging area samples were statistically similar, but were different from the control samples $(\mathrm{P}<0.05)$. Control samples had mean value of $0.78 \%$ and $1.34 \%$ for 
organic carbon and organic matter respectively, which is lower than and statistically different with $1.31 \%$ and $1.70 \%$, and $2.27 \%$ and $2.94 \%$ for old and new effluent discharging areas respectively.

There is significant $(\mathrm{P}<0.05)$ difference between the samples in terms of total nitrogen content. Higher mean values of total nitrogen were observed on samples from the effluent discharging areas. There was significant difference $(\mathrm{P}<0.05)$ between the samples. The results indicated phosphorous has significant difference between new effluent discharging area and the other areas. Abattoir effluent discharge had effect on exchangeable calcium and sodium, but showed no significant effect on exchangeable potassium and magnesium. $3.17 \mathrm{Cmol} / \mathrm{kg}, 3.09 \mathrm{Cmol} / \mathrm{kg}$ and $2.31 \mathrm{Cmol} / \mathrm{kg}$ were the mean exchangeable magnesium values for new abattoir effluent discharging area samples, control area samples and old effluent discharging area samples respectively. These are statistically different from one another $(\mathrm{P}<0.005)$. The cation exchange capacity of the soil samples with mean $8.64 \mathrm{Cmol} / \mathrm{kg}$ was observed for new effluent discharging area, which was statistically the same with $8.70 \mathrm{Cmol} / \mathrm{kg}$ for the old effluent discharging area samples. Significant effect of effluent discharge was observed on the percentage base saturation. base saturation of $68.43 \%$ and electricity conductivity of 5.43 was observed for the control area samples, which was higher than and statistically different from $55.29 \%$ and $46.04 \%$ for new and old effluent discharging areas and the same in EC with mean of 5.96 respectively. Results shows mean of three replicates in old and new site area indicates significant difference from control $(\mathrm{p}<0.05)$.In assessing the impacts abattoir waste generation on the soil physicochemical properties in different level of distances from $10 \mathrm{~m}, 20 \mathrm{~m}$ and $30 \mathrm{~m}$, the result showed significant differences $(p \geq 0.5)$. The $\mathrm{pH}$ of the abattoir waste on soil samples (Table 3 ) was observed to decrease significantly $(\mathrm{p}<0.05)$ compared to control soil samples. The observed decrease in $\mathrm{pH}$ is associated with decaying of organic matter in abattoir which alters the soil $\mathrm{pH}$. This is in line with report of Omole and Ogbiye (2013) that Soil acidity radically affects nutrient availability of plants which presently affects seed germination and crop yield. Increase in soil acidity with decreasing distance to the abattoir site is in accordance with the findings of Iwuagwu and Ugwuanyi (2014) and Nnaji et al., (2016) who observed a decrease in soil $\mathrm{pH}$ of abattoir sites effluents when discharged is acidic but gradually becomes alkaline as biodegradation takes place (Hemming, 1997). The low $\mathrm{pH}$ values on both old and new effluent discharging areas indicated that abattoir effluent had the ability to lower the $\mathrm{pH}$ value of soils. This is in line with the findings of Rabah et al. (2010), whose results revealed lower $\mathrm{pH}$ on abattoir effluent contaminated soil, and high $\mathrm{pH}$ on uncontaminated soil. (Johnbosco et al., 2009; Odoemelan, and Ajunwa, 2008). The new effluent discharging area had the highest nitrogen mean value of $2.81 \mathrm{mg} / \mathrm{kg}$ than the old effluent discharging and control sample area. This is attributed to the washing away of faeces that is known to contain undigested protein, excess nitrogen from digested protein (Omole and Longe, 2008), high total nitrogen content of the soil enhances microbial proliferation and promotes plant growth (Norton et al., 2002). The new effluent discharging area on available phosphorous had $5.28 \mathrm{mg} / \mathrm{kg}$ than the old effluent discharging area and control area. This is consistent to the findings of Rabah et al. (2010), who reported similar high mean available phosphorus value of $5.60 \mathrm{mg} / \mathrm{kg}$ for abattoir effluent contaminated soil and $5.20 \mathrm{mg} / \mathrm{kg}$ for uncontaminated soil (Neboh et al., 2013). The two-exchange magnesium means values prove to be statistically different. These conforms to the findings of Rabah et al. (2010) and Neboh et al. (2013), who also reported higher cation exchange capacity values for abattoir effluent contaminated soil (Thomas, 1982). Electrical exchange means values prove to be statistically different with the mean value of $7.22 \mathrm{Cmol} / \mathrm{kg}$ observed for the control area samples. Electrical conductivity mean values were 5.43 and 5.96 and the control is statistically lower with 3.26 respectively. Electrical conductivity (EC) is a measure of the amount of salts in soil and it may be inferred that the higher mean EC value in the soil means higher deposition of dissolved ions from the effluent (Akinro et al., 2009).

Conclusion: The results obtained indicated that the quality of the soil is negatively affected by the activities of the abattoir. The mean soil $\mathrm{pH}$ value of the control samples was 6.09, which falls within the limits given by the Federal Ministry of Environment. Higher exchangeable sodium $\left(\mathrm{Na}^{+}\right)$value was observed on the new effluent discharging area samples. Excess level of sodium ions in the soil disperses fine particles into pores, thereby reducing water penetration and blocking root access. The study recommends that regular inspection of abattoirs and strict enforcement of law be made to reduce environmental contamination.

\section{REFERENCES}

Adeyemo, O; Adeyemi, I; Awosanya, E (2009). Cattle cruelty and risks of meat contamination at Akinyele cattle market and slaughter slab in Oyo State, Nigeria. Trop. Anim. Health. Prod. 41, 1715- 1721. 
Akinro, AO; Ologunagba, IB; Olotu, Y (2009). Environmental implications of unhygienic operation of a city abattoir in Akure, Western Nigeria. ARPN Int. J. Biosci. (2011) J. Engineer. Appl. Sci. 4, 311-315.

Aniebo, AO; Wekhe, SN; Okoli, IC (2009). Abattoir Blood Waste Generation in River State and its Environmental Implications in the Niger Delta. Toxic. Environ. Chem. 91:619-625.

Bates, RG (1954). Electrometric $\mathrm{pH}$ determinations. New York, USA: John Wiley and Sons Inc. pp: 29.

Bello, YO; Oyedemi, DT (2009). The Impact of Abattoir Activities and Management in Residential Neighbourhoods: A Case Study of Ogbomoso. Niger. J. Soc. Sci. 19 (2): 121-127.

Bray, RH; Kurtz, LT (1945). Determination of total, organic, and available forms of phosphorus in soils. Soil Sci. J. 59: 39-45

Bremner, MJ; Mulvaney, CA (1982). Total nitrogen in: L. G. Page (ed), Methods of soil analysis. Agronomy monograph. 9. America society agronomy. Madison: Wisconsin. pp: 891-901.

Chukwu, O (2008). Analysis of groundwater pollution from abattoir waste in Minna, Nigeria. Res. J. Diary Sci. 2, 74-77.

Chukwu, O; Adeoye, PA; Chidiebere, I (2011). Abattoir wastes generation, management and the environment: a case of Minna, North Central Nigeria. Inter. J. Biosci. 1 (6) 100-109

Gauri, SM (2006). Treatment of wastewater from abattoirs before land application: a review. Biores. Technol. 97, 1119 - 1135.

Hemming, ML (1977). A viable solution to the palm oil effluent problem. In: Earp D.A. and Newall W. (Eds). Proceedings of the Malaysian International Symposium on Palm Oil Processing and Marketing. Kuala Lumpur, pp. 79-95.

Iwuagwu, JO; Ugwuanyi, JO (2014). Treatment and Valorization of Palm Oil Mill Effluent through Production of Food Grade Yeast Biomass. Article ID 439071.

http://dx.doi.org/10.1155/2014/439070

Johnbosco E U; Braide, SA; Chindah, AC (2009). Impact of abattoir wastes based on some physicochemical parameters on Woji Creek, Port Harcourt, Nigeria. Int. J. Manage. Environ. Qual. 20(5), 581-591.

Keay, R. WJ (1989). An outline of Nigeria vegetation. A revised edition of Nigerian trees. Laxendan press Oxford.pp.318-339

Nnaji, JC; Okoye, JA; Omotugba, SK (2016). Soil quality in the vicinity of palm oil mills in Umuahia, Nigeria. Inter. Res. J. Chem. Chem. Sci. 3 (1). 029-032.

Muhirwa, D; Nhapi, I; Wali, U; Banadda, N; Kashaigili, J; Kimwaga R (2010). Characterization of wastewater from an abattoir in Rwanda and the impact on downstream water quality. Inter. J. Ecol. Develop. 16, 30-46.

Neboh, HA, Ilusanya, OA; Ezekoye, CC; Orj, FA (2013). Assessment of ijebu-igbo abattoir effluent and its impact on the ecology of the receiving soil and river. J. Sci. Toxic. Food Technol. 7(5): 23192402.

Norton, LD; Hainberg, S; Gweck, L; Edwards JR; James, H (2002). Erosion and soil chemical properties. An MSc. Thesis. Uganda: University of Agriculture. pp: 15-17.

NPC. (2006). National Population Census 2006.

NRCRI. (2002). Meteorological and soil science reports unpublished reports of the meteorological and soil science division, national root crop research institute, (NRCRI), Umudike.

Nwachukwu VC (2006). Analysis of Nsukka municipal Abattoir solid waste and its microbial contents in Enugu State, Nigeria. A DVM project, Dpt. of Vet. Public Health and Preventive Medicine, University of Nigeria, Nsukka, Nigeria

Odoemelan, SA; Ajunwa, O (2008). Heavy Metal Status and physicochemical properties Agricultural Soil by short term application of animal manure. J Chem. Soc. Nig. 20:60-63.

Omole, DO; Longe, EO (2008). An assessment of the impact of abattoir effluents on river Illo, Ota, Nigeria. J. Environ. Sci. Technol. 1(2): 56-64.

Omole, DO; Ogbiye, AS (2013). An evaluation of slaughterhouse wastes in south-west Nigeria. Am. J. Environ. Protect. 2(3): 85-89 
Osemwota, O (2010). Effect of abattoir effluent on the physical and chemical properties of soils. Environ. Monit. Assess. 167, 399-404.

Osibanjo, O; Adie, GU (2007). Impact of effluent from Bodija abattoir on the physico-chemical parameters of Oshunkaye stream in Ibadan city, Nigeria. Afr. J. Biotech. (6):1806-1811.

Rabah, A.B; Oyeleke, SB; Manga, SB; Hassan, LG; Ijah, UJ (2010). Microbiological and physicochemical assessment of soil contaminated with abattoir effluents in Sokoto metropolis, Nigeria. Sci. World J. 5(3): 1-4.

Singh, VP; Neelam, S (2011). A survey report on Impact of Abattoir Activities Management on management in the Tamale metropolis: Case study of the Tamale slaughterhouse. J. Public Health. Epidemiol. 6(1). 14-19.

Thomas, GW (1982). Exchangeable cations. In A. I. Page, R. H. Miller, \& D. R. Keeney (Eds.), Methods of soil analysis part 2, Agro. Monogr 9, 2nd ed. pp. 159-165.

Walkley, A; Black, IA (1934). An examination of the degtjarett method of determining soil organic matter and proposed modification of the chromic acid titration method. Soil Sci. (37): 29-38.

Zaku, SG; (2006). Quality assessment of soil in Donga, Ibi and Wukari local government areas in Taraba State. M. Tech Dissertation. Federal University of Technology, Yola. 